\title{
Follicle Stimulating Hormone Beta Polypeptide
}

National Cancer Institute

\section{Source}

National Cancer Institute. Follicle Stimulating Hormone Beta Polypeptide. NCI Thesaurus. Code C65746.

A pharmacologic form of follicle-stimulating hormone used in the treatment of infertility. 